\title{
Election to the Fellowship: Dr Anatoly Koryagin
}

Dr Anotoly Koryagin, who is on hunger strike in prison. Is a Soviet psychiatrist who took a firm and principled stand against the misuse of psychiatry in the USSR. He received a sentence of seven years' imprisonment and five years in exile in February 1981. He was elected to the Membership of the College as a medical graduate of 'exceptional distinction' in February 1983. He was first eligible to be elected a Fellow this year and it was Dr Koryagin's professional standing that has now led to his election. When the President wrote to him to inform him of his election, he stated:

The Court of Electors of the Royal College of Psychiatrists elected you to the Fellowship of the College on Monday 11 February. With my personal congratulations. I enclose a copy of the formal Certificate notifying you of this distinction.

I, personally, and the Council of the College, for whom I speak. have been very distressed to hear of the dreadful condition you are in, being on hunger strike in the Chistopol Prison. We understand that you were provoked into this strike by escalating physical brutality and will not end it until you receive assurances of proper treatment. I have previously written on behalf of the College to the Governor of the Chistopol Prison, the Soviet Embassy in London and to the Secretary General of the World Psychiatric Association to draw to the attention of the authorities our very grave concern about your condition.

I can only end by saying that your stand for human rights and your actions to prevent abuses of psychiatry command the admiration of your professional colleagues far beyond the boundaries of the USSR.

$\checkmark$

The President has also written to The Times (6 March 1985). The College remains extremely concerned about Dr Koryagin's plight and will continue to use its best endeavours to see that it is ameliorated. One way that this can be done is for individual members of the College to write to Dr Koryagin himself at USSR 422950, Tatarskaya ASSR, g. Chistopol, uchr. U3-148/st-4, and also to the Governor of the Chistopol Prison, Captain Romanov, Tatarskaya, USSR. Letters might refer to Article 100 of the RSFSR Corrective Labour Code which specifies that 'convicted persons suffering from chronic mental illness or another grave illness which prevents further serving of punishment may be released by a court from further serving of punishment.'

\section{Correspondence}

\section{Dr Anatoly Koryagin}

DeAR SiRs

We are writing to appeal to members of the College urgently to join us in trying to save the life of our colleague and fellow member of the College, Dr Anatoly Koryagin, who is dangerously ill in a Soviet prison. As you will know, Dr Koryagin was arrested in 1981 and given a 12-year sentence for publicly criticizing the Soviet authorities' practice of interning dissenters in psychiatric hospitals without medical justification.

Since then the authorities have been steadily increasing the mental and physical pressures upon him in an attempt to force him to renounce his views. His response to this mounting campaign has been a corresponding increase of resistance in the form of protracted hunger strikes, a means frequently used by Soviet political prisoners to defend their minimal rights. In spite of forcible feeding. Dr Koryagin's condition has deteriorated alarmingly. When his wife and children visited him in August 1983 he was suffering from acute protein deficiency and his body was badly swollen. He has been severely beaten by prison warders.

In October 1984 we learnt that he was physically unable to end another four-month hunger strike, although he wanted to, but could neither chew nor swallow. At that time Amnesty International appealed to doctors throughout the world to intercede on his behalf. Then at the end of
January this year, we heard that he was on hunger strike again and was still unable to stand. We greatly fear that the authorities, having failed to extract the required recantation, may decide that his death would be the most convenient alternative. Several Soviet political prisoners have died recently and unless we add our voices to the international clamour on this brave man's behalf, the same may happen to Anatoly Koryagin. He was elected a Member (and now Fellow) of the Royal College of Psychiatrists in recognition of his courageous defence of the ethics of our profession and we now have an obligation to help him.

In a smuggled letter from prison. Dr Koryagin himself appealed for our help and support and we cannot sit back and allow him to die. Our College has already intervened vigorously on his behalf. This, however, is not enough. It is now necessary for every individual member to do likewise if we are to save his life and secure his early release. We urge you most strongly to write for details of recommended action to the first of the three signatories below.

ANTHONY ClaRE

Department of Psichological Medicine

Si Burtholomen's Hospital Medical School

London ECl

Also signed b!: KENNETH RAWNSLEY MARTIN ROTH 